\title{
Hepatitis C: Prevention and Management
}

\section{Naglaa Gamil Shehab*}

Pharmacognosy Department, Faculty of Pharmacy, Dubai Pharmacy College, Dubai, UAE

\section{General Introduction}

The liver is an organ that does many important things. The main functions of the liver are removing harmful chemicals from the blood, fighting infection, helping in digestion, Storing nutrients and vitamins especially fat soluble vitamins, transferring the excess glucose into glycogen and breaking down the glycogen into glucose in case of deficiency.

Hepatitis $C$ is a liver disease. Hepatitis means inflammation of the liver. Anyone can get hepatitis $\mathrm{C}$, but some people are at higher risk, including patient who was born to a mother with hepatitis $\mathrm{C}$, patient who has had more than one sex partner in the last 6 months or has a history of sexually transmitted disease, patient who had a blood transfusion or organ transplant before July 1992, patient with hemophilia who received blood products before 1987 and patient who has used illegal injection drugs.

\section{Types of Hepatitis C}

\section{Acute Hepatitis C}

Acute hepatitis $\mathrm{C}$ is diagnosed on the basis of symptoms such as jaundice, fatigue, and nausea, along with marked increases in serum ALT (usually greater than 10-fold elevation), and presence of anti$\mathrm{HCV}$ or de novo development of anti-HCV.

Diagnosis of acute disease can be problematic because anti-HCV is not always present when the patient presents to the physician with symptoms. In 30 to 40 percent of patients, anti-HCV is not detected until 2 to 8 weeks after onset of symptoms. Acute hepatitis $C$ can also be diagnosed by testing for HCV RNA, but another approach is to repeat the anti-HCV testing a month after onset of illness.

\section{Chronic Hepatitis C}

Chronic hepatitis $\mathrm{C}$ is diagnosed when anti-HCV is present and serum aminotransferase levels remain elevated for more than 6 months. Testing for HCV RNA (by PCR) confirms the diagnosis and documents that viremia is present; almost all patients with chronic infection will have the viral genome detectable in serum by PCR.

Diagnosis is problematic in patients who cannot produce antiHCV because they are immunosuppressed or immunoincompetent. Thus, HCV RNA testing may be required for patients who have a solidorgan transplant, are on dialysis, are taking corticosteroids, or have agammaglobulinemia. Diagnosis is also difficult in patients with antiHCV who have another form of liver disease that might be responsible for the liver injury, such as alcoholism, iron overload, or autoimmunity. In these situations, the anti-HCV may represent a false-positive reaction, previous $\mathrm{HCV}$ infection, or mild hepatitis $\mathrm{C}$ occurring on top of another liver condition. HCV RNA testing in these situations helps confirm that hepatitis $\mathrm{C}$ is contributing to the liver problem.

\section{Symptoms of Hepatitis C}

Most people have no symptoms until the virus causes liver damage, which can take 10 or more years to happen. Others have one or more of the following symptoms: yellowish eyes and skin, called jaundice, swollen stomach or ankles, easy bruising, tiredness, upset stomach, fever, loss of appetite, diarrhea, light-colored stools and dark yellow urine.
A hepatitis $\mathrm{C}$ infection can cause damage to patient liver (cirrhosis). If the patient develops cirrhosis, he may have:

- Redness on the palms of patient hands caused by expanded small blood vessels.

- Clusters of blood vessels just below the skin that look like tiny red spiders and usually appear on patient chest, shoulders, and face.

- Swelling of patient belly, legs, and feet.

- Shrinking of the muscles.

- Bleeding from enlarged veins in patient digestive tract, which is called variceal bleeding.

\section{Herbal Treatment and Protection}

\section{Milk thistle (Silybum marianum)}

Amazing herb protects the liver cells from damaging molecules called free radicals. It inhibits production of leukotriene'sinflammatory compounds responsible for some types of liver damage and boosts the production of glutathione also it stimulates the flow of bile helping the digestive system to do its work. This herb helps in increasing the liver cell regeneration when damage.

Dose: 70 to 210 milligrams of capsules containing milk thistle's active ingredient.

\section{Dandelion Root (Taraxacum officinale)}

The bitter constituents in the root enhance liver function by increasing production of bile and improving gallbladder function. Dandelion also contains choline that's involved in normal liver function. Dandelion root is rich in vitamins and minerals, improves digestion, and may even lower cholesterol.

Dose: cup of tea three times per day.

\section{Turmeric (Curcuma domastica)}

Turmeric's antioxidant properties protect the liver from numerous toxic chemicals. Turmeric has been reduced cancer-causing agents in the urine of smokers, lowering of these toxins in the body.

Typical dosage: three times a week, - or take 500 milligrams in capsules two to three times per day.

\section{Schisandra (Schisondra chinensis)}

The plant protects the liver from damage by a variety of its

*Corresponding author: Naglaa Gamil Shehab, Pharmacognosy Department, Faculty of Pharmacy, Dubai Pharmacy College, Dubai, UAE, Tel: 971503212716; Tel: +60164230950, E-mail: naglaa_shehab@hotmail.com

Received March 24, 2014; Accepted March 25, 2014; Published March 27, 2014

Citation: Shehab NG (2014) Hepatitis C: Prevention and Management. Nat Prod Chem Res 2 :e108. doi:10.4172/2329-6836.1000e108

Copyright: (c) 2014 Shehab NG. This is an open-access article distributed under the terms of the Creative Commons Attribution License, which permits unrestricted use, distribution, and reproduction in any medium, provided the original author and source are credited. 
antioxidant effects gradually improves overall health chronic stress is part of the life.

Typical dosage: up to six 580-milligram capsules per day or 1 cup of tea three times per day.

\section{Conclusion}

Hepatitis $\mathrm{C}$ is very dangerous disease now a day which always changes to cancer in liver if it does not discover early. Regular checkup should be done for both Hepatitis C and Cancer liver every one year. The early discovering hepatitis $\mathrm{C}$ the easily treating and also decrease the percentages of changing it to cancer in liver. 